\title{
Did the Neanderthals Produce Complex Speech?
}

\author{
Krzysztof Izdebski1,2,3*, Herbert Dedo4, Raul M. Cruz ${ }^{5,6}$, Alysson R. Muotri7 \\ ${ }^{1}$ Chairman of the Pacific Voice \& Speech Foundation, San Francisco, CA, USA \\ ${ }^{2}$ Vice President of The World Voice Consortium, Oporto, Portugal \\ ${ }^{3}$ San Francisco Conservatory of Music, San Francisco, CA, USA \\ ${ }^{4}$ Otolaryngology, Head and Neck Surgery, UCSF, San Francisco, CA, USA (Died, August 2021) \\ ${ }^{5}$ Vice-Chair of the Pacific Voice \& Speech Foundation, San Francisco, CA, USA \\ ${ }^{6}$ Chief of Voice Clinic at the Head \& Neck Surgery Department \& HNS Residency Program Director, Kaiser Permanente, \\ Oakland, CA, USA \\ ${ }^{7}$ Departments of Pediatrics and Cellular \& Molecular Medicine, Director of the Stem Cell Program and Archealization Center, \\ University of California, San Diego, La Jolla, CA, USA \\ Email: ${ }^{\star}$ kizdebski@pvsf.org
}

How to cite this paper: Izdebski, K., Dedo, H., Cruz, R. M., \& Muotri, A. R. (2021). Did the Neanderthals Produce Complex Speech? Open Journal of Modern Linguistics, 11, 849853.

https://doi.org/10.4236/ojml.2021.116065

Received: September 22, 2021

Accepted: November 23, 2021

Published: November 26, 2021

Copyright $\odot 2021$ by author(s) and Scientific Research Publishing Inc. This work is licensed under the Creative Commons Attribution International License (CC BY 4.0).

http://creativecommons.org/licenses/by/4.0/

\begin{abstract}
Purpose: Paleoanthropologists link the discovery of the modern human-like hyoid bone (HB) in Neanderthal skeleton remains at Kebara Cave (Israel) as the pivotal evolutionary step associated with speech development. This finding is cited as evidence Neanderthals produced complex speech, yet this association remains controversial. Conclusion: Here, we present clinical and scientific evidence challenging the pivotal role of the HB in producing speech, and suggest that CNS development was more fundamental than the presence of HB to speech production.
\end{abstract}

\section{Keywords}

Modern Human-Like Hyoid Bone, Speech Development, Neanderthals

\section{Introduction}

Paleoanthropologists, scientists dedicated to the studies of human evolution from ancient fossils suggest that speech was possible when the Neanderthals finally evolved a particular bone, called the hyoid bone, (HB; Whipps, 2008). This is based on a 1983 finding of a modern-looking HB in a Neanderthal skeleton located at Kebara Cave on Mount Carmel (Israel), and subsequent findings elsewhere (Lieberman \& Crelin, 1971). The Kebara finding supposedly "settled an old debate over the question whether the Neanderthals could speak" (Papagiani- 
ni \& Morse, 2013: p. 115). A detailed study of HB micro-biomechanics supports the idea that the Kebara Neanderthal spoke but is inconclusive concerning complex language (D'Anastasio et al., 2013). Others, however, still contest the role of the $\mathrm{HB}$ as key evidence whether or not Neanderthals could speak (de Boer, 2012). Nonetheless, most recent literature provides valid arguments in support of the presence of speech, even language in this population. For example, a very recent article (Schuster, 2021) supports that the Neanderthals could speak and had a language by invoking data from Conde-Valverde's and her group (2021) study entitled "Neanderthals and Homo sapiens had similar auditory and speech capacities". Schuster states that "a new multidisciplinary approach, based on fossil evidence and modeling claims to have categorically proven that they (Neanderthals) did (spoke)". This opinion is further supported by genetic observations that Neanderthals and modern humans shared the same sequence of the language-related Foxp2 gene associated with brain development (Krause et al., 2007; Trujillo et al., 2021). Moreover, a 2018 online article by Dediu and Levinson (2018) supports the notion that "The new data supports language and speech being old and shared with archaic humans. However, this does not rule out subtle and very interesting differences". In all, our objective is not to challenge the possibility that the Neanderthals could speak or had developed language, as much as we challenge that the presence of the hyoid bone in paleontological fossil findings is pivotal to the ability to speak.

\section{Discussion}

Here, we challenge assigning a pivotal role of the $\mathrm{HB}$ in the development of speech. Our challenge to this assumption is based on the scientific and clinical evidence from the following fields that the four authors represent: speech science, speech pathology, phonetics, linguistics, medical laryngology, head and neck surgery, molecular medicine, neurosciences, stem cell, and archealization research.

From our collective perspective, we do not question the evidence documenting the presence of the $\mathrm{HB}$ and its level in the neck of Neanderthals. Nor are we disregarding the evidence that Neanderthals may have produced complex speech. However, we challenge linking the presence and location of the $\mathrm{HB}$ as the pivotal evolutionary step in producing complex speech. We appreciate that predominantly given an ancient bony fossil record to interpret evolutionary change, there could be a tendency to over-value such paleontological findings as evidence of speech acquisition/production.

We believe that speech development, complex or not, relies on progressive central nervous system (CNS) function, not the presence of a bone. In our opinion, CNS progression in cognitive ability and nuanced motor control of the entire vocal tract (from lungs to lips) resulted in speech development. Consequently, we present eight arguments that the HB has little or nothing to do with speech production, which requires developed CNS function. Arguments we present are based on our scientific and clinical experience concerning normal and abnormal 
voice, speech, and language production in contemporary humans (Tantam et al., 1993; National Institute on Deafness and Other Communication Disorders, n.d.; Askar et al., 2017; Lübben et al., 2001; Dedo, 1990; Izdebski et al., 1994; Izdebski et al., 1987).

\section{Arguments}

First, the HB is not the exclusive property of Homo sapiens, as it is present in many vertebrates. Many of these vertebrate animals can produce various sound signals but not complex or even simple speech-only calls, howls, or barks.

Second, many modern humans with autism spectrum disorders and other conditions with cognitive dysfunction have a functional HB but cannot generate speech (Tantam et al., 1993).

Third, in expressive aphasia, a loss of the brain's ability to send neural commands to the speech organs to create phonation coordinated with articulation causes loss or severely restricted speech production in the presence of a normal HB (NIDCD, n.d.).

Fourth, surgical alteration of the HB in surgery (for sleep apnea in adults or cysts in children) has almost always been reported to not affect speech except in extraordinary circumstances (Askar et al., 2017; Lübben et al., 2001).

Fifth, removing the entire larynx, including the $\mathrm{HB}$, in cancer surgery eliminates the primary voice organ, the larynx. However, rehabilitative methods have been developed that produce speech even in the absence of the larynx and $\mathrm{HB}$, but with adequate CNS function (Dedo, 1990; Izdebski et al., 1994).

Sixth, speech (articulation) is seriously altered when the tongue, the major articulation organ, is affected or removed while the HB remains intact. An artificial tongue placed intraorally will, however, significantly enhance speech intelligibility (Izdebski et al., 1987).

Seventh, the HB and the vertical larynx position (VLP) in the neck are claimed to be crucial for the creation of voice and complex speech (Lieberman \& Crelin, 1971). In reality, VLP has little to do with these claims, specifically in the context of creating a complex speech, which typically is defined as an ability to express thoughts including expressing emotions (Izdebski, 2006). The height of the HB in the neck has no bearing on our ability to speak (in any form, complex or not) but can affect voice quality (Shipp \& Izdebski, 1975).

Eighth, current genetic research further extrapolates support for the Foxp2 gene changes in Neanderthals and Homo sapiens advancing neurodevelopment associated with speech over lower hominins (Trujillo et al., 2021).

\section{Conclusion}

In conclusion, attempts at dating speech development rest in our opinion too heavily on interpretations of paleontological data relating to the presence and location of the HB in the neck. More likely, complex speech is related to the progressive development of brain function that is not reflected in the anatomical 
fossil record. Speech, in our opinion, necessitates a dual higher CNS functionthe cognitive ability to formulate thoughts and nuanced motor capabilities to articulate them, not the presence of a single bone.

\section{Acknowledgements}

We recognize Clara Lewis, B.A., for her contributions to editing this manuscript. We dedicate this work to our co-author, Dr. Herbert H. Dedo, who passed in August 2021 and who in his wisdom discussed this issue with us on many occasions and kept on encouraging us to gather solid evidence and valuable arguments in support of our position.

\section{Conflicts of Interest}

The authors declare no conflicts of interest regarding the publication of this paper.

\section{References}

Askar, S. M., Quriba, A. S., Hassan, E. M., Awad, A. M., \& Bessar, A. A. (2017). Voice and Swallowing Outcomes after Hyoid Suspension Surgery in Patients with Obstructive Sleep Apnea. Folia Phoniatrica et Logopaedica, 69, 271-277. https://doi.org/10.1159/000488239

Conde-Valverde, M., Martínez, I., Quam, R. M., Rosa, M., Velez, A. D.,Lorenzo, C., Jarabo, P., Bermúdez de Castro, J. M., Carbonell, E., \& Arsuaga, J. L. (2021). Neanderthals and Homo Sapiens had Similar Auditory and Speech Capacities. Nature Ecology \& Evolution, 5, 609-615. https://doi.org/10.1038/s41559-021-01391-6

D’Anastasio, R., Wroe, S., Tuniz, C., Mancini, L., Cesana, D. T., Dreossi, D., Ravichandiran, M., Attard, M., Parr, W. C. H., Agur, A., \& Capasso, L. (2013). Micro-Biomechanics of the Kebara 2 Hyoid and Its Implications for Speech in Neanderthals. PLoS ONE, 8, Article ID: e82261. https://doi.org/10.1371/journal.pone.0082261

de Boer, B. (2012). Loss of Air Sacs Improved Hominin Speech Abilities. Journal of Human Evolution, 62, 1-6. https://doi.org/10.1016/j.jhevol.2011.07.007

Dediu, D., \& Levinson, S. C. (2018). Neanderthal Language Revisited: Not Only Us. Current Opinion in Behavioral Sciences, 21, 49-55. https://doi.org/10.1016/j.cobeha.2018.01.001

Dedo, H. H. (1990). Surgery of the Larynx and Trachea. B.C. Decker.

Izdebski, K. (2006). Emotions in the Human Voice (Vol. 1-3). Plural Publishing.

Izdebski, K., Reed, C. G., Ross, J. C., \& Hilsinger Jr., R. L. (1994). Problems with Tracheoesophageal Fistula Voice Restoration in Totally Laryngectomized Patients. A Review of 95 Cases. Archives of Otolaryngology-Head \& Neck Surgery, 120, 840-845. https://doi.org/10.1001/archotol.1994.01880320042010

Izdebski, K., Ross, J. C., Roberts, W. L., \& de Boie, R. G. (1987). An Interim Prosthesis for the Glossectomy Patient. The Journal of Prosthetic Dentistry, 57, 608-611. https://doi.org/10.1016/0022-3913(87)90345-3

Krause, J., Lalueza-Fox, C., Orlando, L., Enard, W., Green, R. E., Burbano, H. A., Hublin, J. J., Hänni, C., Fortea, J., de la Rasilla, M., Bertranpetit, J., Rosas, A., \& Pääbo, S. (2007). The Derived FOXP2 Variant of Modern Humans Was Shared with Neandertals. Current Biology, 17, 1908-1912. https://doi.org/10.1016/j.cub.2007.10.008 
Lieberman, P., \& Crelin, E. (1971). On the Speech of Neanderthal Man. Linguistic Inquiry, 2, 203-222.

Lübben, B., Alberty, J., Lang-Roth, R., Seifert, E., \& Stoll, W. (2001). Thyroglossal Duct cyst Causing Intralaryngeal Obstruction. Otolaryngology-Head and Neck Surgery, 125, 426-427. https://doi.org/10.1067/mhn.2001.117168

National Institute on Deafness and Other Communication Disorders (NIDCD) (n.d.). Aphasia: What Is Aphasia? https://www.nidcd.nih.gov/health/aphasia

Papagianini, D., \& Morse, M.A. (2013). The Neanderthals Rediscovered: How Modern Science is Rewriting Their Story. Thames and Hudson.

Schuster, R. (2021, March 2). Neanderthals Could Speak, New Study Claims to Prove. Haaretz.

https://www.haaretz.com/archaeology/neanderthals-could-speak-new-study-claims-toprove-1.9581958

Shipp, T., \& Izdebski, K. (1975). Vocal Frequency and Vertical Larynx Positioning by Singers and Nonsingers. The Journal of the Acoustical Society of America, 58, 1104-1106. https://doi.org/10.1121/1.380776

Tantam, D., Holmes, D., \& Cordess, C. (1993). Nonverbal Expression in Autism of Asperger Type. Journal of Autism and Developmental Disorders, 23, 111-133. https://doi.org/10.1007/BF01066422

Trujillo, C. A., Rice, E. S., Schaefer, N. K., Chaim, I. A., Wheeler, E. C., Madrigal, A. A., Buchanan, J., Preissl, S., Wang, A., Negraes, P. D., Szeto, R. A., Herai, R. H., Huseynov, A., Ferraz, M., Borges, F. S., Kihara, A. H., Byrne, A., Marin, M., Vollmers, C., Brooks, A. N., Lautz, J. D., Semendeferi, K., Shapiro, B., Yeo, G. W., Smith, S. E. P., Green, R. E., \& Muotri, A. R. (2021). Reintroduction of the Archaic Variant of NOVA1 in Cortical Organoids Alters Neurodevelopment. Science, 371, Article No. eaax2537. https://doi.org/10.1126/science.aax2537

Whipps, H. (2008). How the Hyoid Bone Changed History. LiveScience. https://livescience.com/7468-hyoid-bone-changed-history.html 